\title{
Organizational Change and Employee Concerns in the Finnish Defence Forces'
}

\section{Minna Leinonen²}

Postdoctoral Research Fellow, Work Research Centre, University of Tampere, Finland

\section{Risto Nikkanen}

Researcher, Work Research Centre, University of Tampere, Finland

\section{Katri Otonkorpi-Lehtoranta ${ }^{3}$}

Postdoctoral Researcher, Work Research Centre, University of Tampere, Finland

\begin{abstract}
The Finnish Defence Forces (FDF) have, in accordance with other public sector organizations in the Nordic countries, undergone many change processes in this millennium. Changes in the FDF have been related to government savings and more recently the fluctuating security environment. The purpose of the study is to show how these change processes have meant somewhat different things to men and women in the FDF, and these differences have an intersectional character. In order to explain, how potent experienced changes are in explaining the concerns of the personnel, and how they possibly interact with gender, age and personnel group, we analyzed survey data by using logistic regression. The survey was addressed to all salaried personnel of the FDF in 2015. The analysis showed that the logic of the examined, personally experienced, organizational changes deepened divisions produced by civil/military and gender hierarchies.
\end{abstract}

\section{KEYWORDS}

Gender / intersectionality / military / organizational change / public sector

\section{Introduction}

he Finnish working life has suffered from the intensification of work and rising insecurity. These trends have affected white- and blue-collar employees. Until recently, women had gained on men in opportunities for access to and work in high-quality jobs. However, the austerity politics that have strained female-dominated occupations in the Finnish public sector have also meant weakening working conditions (Mustosmäki et al. 2016, 240-241). The public sector has undergone significant changes that are in many ways linked to new public management (NPM). In Finland, the rise of NPM has strongly emphasized the government program for productivity. Since the start of the new millennium, NPM strongly shaped public sector reforms, which have been understudied.

\footnotetext{
${ }^{1}$ You can find this text and its DOI at https://tidsskrift.dk/njwls/index.

${ }^{2}$ Corresponding author: Minna Leinonen. E-mail: minna.leinonen@uta.fi

${ }^{3}$ Corresponding author: Katri Otonkorpi-Lehtoranta. E-mail: katri.Otonkorpi-Lehtoranta@uta.fi
} 
The program for productivity is said to have been motivated by concerns for the development of the private sector and the aging of the population. Although the program operates under the banner of increasing productivity, in practice, this has meant reducing the number of government personnel and decreasing the volume of government activities. In the process, focusing on the so-called core tasks has also meant legislative changes that, in turn, have resulted in redefinitions of those core tasks. In all, the program has strengthened the position of productivity in steering. (Herranen 2015, 27, 34, 36)

Above-mentioned changes have applied to the security and defence policy and the military, too. The Finnish Defence Forces (FDF) have faced many change processes for more than 20 years caused by government savings and more recently the fluctuating security environment. We approach personnel's experiences on organizational changes such as shutting down divisions and personnel transfers by analyzing the concerns they have raised. We are interested in whether the employees who have experienced organizational changes have more concerns than those who have not experienced same kinds of changes.

Untypically for a public sector organization, the FDF has a high representation of men. Of 12,000 employees, around $82 \%$ were men at the end of 2016. Men work mainly in military jobs as soldiers (8000) and women in the support sector as civilians (4000). The majority of soldiers are men, but civilians are almost equally both genders. As we aim to show in this research, organizational changes have meant somewhat different things to men and women in the FDF, and these differences have an intersectional character. The cutbacks in personnel have affected civilian personnel in particular. The FDF has been a steady employer in many areas in Finland, but the changes, especially in recent years, have made the job situation insecure.

\section{Organizational change within military organizations}

There is a large body of research explaining military change in the field of organization studies. Military organizations have been considered conservative and resistant to change. However, later literature on military change has shed light on the complexity of the process of military innovation that includes both internal and external catalysts. Nowadays, it is a matter of common knowledge among scholars that change is continuous in defence sector and military organizations around Europe (Norheim-Martinsen 2016). There are various approaches on why and how the change takes place. Approaches differ from each other in understanding, what is the main catalyst for change, and by what mechanism and processes change becomes possible.

There is a general agreement among scholars that organizational changes within military organizations are interconnected by broader trends of political and societal developments in Europe. It is argued that a gradual development toward industrialized and democratic welfare states reaching back 70 years has marginalized the role of the military in European states (Sheehan 2008). The later knowledge revolution has diminished further the legitimacy of the military as a central societal institution. This development of demilitarization can be traced by considering the role of the military as a state-building institution, the security and defence policy process, and the political and societal role of the military. Welfare states have undertaken new roles and tasks in parallel with changes in the nature of security environment, conflicts, and perceptions of 
threats. Changes in security and defence policy process have challenged the idea of security and military policy as exceptional processes. The equation of security and military policy with other policy areas has set requirement for the same standards of transparency and open debate (Holmberg 2015). In many countries, including Finland, NPM has been utilized as a tool for setting the standards for resources, management, and regulation also in the military (Norheim-Martinsen 2016).

Adopting NPM has meant emphasizing market-oriented approaches to organization, standardization, and commodification of services (Kamp et al. 2013, 1). In accordance with this emphasis, the FDF has entered into partnership contracts with different service providers, and the restructuring of the organization has entailed protecting the military core at the expense of the civilian work performed inside the organization (Tallberg 2009, 2010). Compared with other (Western) military organizations, the FDF organization has similar core functions, and work is organized around these functions. The reaching out to civil society using various kinds of networks will probably rearrange civil-military relations, but its political and normative influence to society is yet to be seen. International cooperation also means pressure to harmonize military work with other countries.

Despite of the similarities with the certain internationally manifested traits of demilitarization (Holmberg 2015), Finnish security and military policy and the FDF also differ from many European counterparts. The closest comparable military organization would be the Swedish Armed Forces, which has recently reintroduced conscription and is not a NATO member. The FDF is based on conscript troops, and conscription makes the FDF a special institution in society, not the least because obligatory military service for men shapes male adulthood and connections between male generations. Women's military service is possible but not mandatory. The compulsory military service and conscript army connected to the surveillance of the country's land area, territorial waters and airspace, as well as safeguarding territorial integrity as a one of three main tasks of the FDF, might retard professionalization while supporting other authorities and participating in international crisis management will presumably influence in the opposite direction.

Recent studies on organizational change within military organizations in Nordic countries have analyzed a process of political and societal demilitarization (Holmberg 2015), cynicism and resistance in military (Bergström et al. 2014), and organizational anorexia (Alvinius et al. 2016), to name but a few. Ola Bergström, Alexander Styhre, and Per Thilander (2014) have pointed out interestingly in their study on organizational cynicism that those regiment managers, who were actively involved and had to deal with the negative consequences of made decisions for organizational change, were more critical or expressed more cynicism than those, who did not have to experience inconsistencies between their everyday realities and decisions made by the headquarters. The authors present that the organizational cynicism should be seen as organizational member's active involvement translating the change process, rather than a sign of resistance to change. In line with Bergström et al., we also focus on experiences of personnel, but from different perspective and theoretical framework. We are interested in how personnel translate organizational change into concerns about their work conditions and well-being at work and how these experiences are intertwined with their gender and occupational status. Our study draws from conceptualizations of inequality regimes and intersectional analysis. Orna Sasson-Levy (2017, 130-132), reminds us that 
'intersectionality analysis provides us with a more complex and nuanced understanding of the military service experience of men and women of different social groups'. However, in our research, we are not interested only in the experiences of those in military roles, but we also see the civilians of the organizations as important to analyze if we want to take the intersectional endeavor seriously.

\section{The Finnish context: organizational change as downsizing}

The FDF is a strongly male-dominated and gender-segregated organization. Women are mainly working in the civilian jobs, whereas military personnel consist predominantly of men. The organization has undergone continuously structural changes, as part of which there has been a decline in the number of civilian jobs due to outsourcing some activities and forming service centers. As a result of changes, the civil-military divide is enforced in the organizational structure. For example, civil and military personnel have different pay systems, pension plans, and upwardly mobile career paths are preserved only for officers. For officers, age is related to successive promotions and early retirement, whereas for civilians, aging does not offer this kind of positive outlook to future career paths.

The most recent and significant organizational change process was implemented in the FDF in 2012-2015. One important reason for the reform was the need for financial savings in public administration. In the FDF, savings were achieved by reducing management levels and by shutting down or merging FDF divisions and units. In addition, the length of the minimum service period for conscripts was shortened. By the beginning of 2015 , the number of salaried personnel were reduced from 14,400 to 12,000 . The number of civilian employees was reduced from 5700 to 4000 and soldier employees from 8700 to 8000 (Defence Command 2016).

The implementation of reforms has resulted in major structural changes. Several FDF divisions and units were shut down, reestablished, or merged into other divisions or units as part of the change process. New units concerning logistics, intelligence, management system, and research services were founded under the Defense Command. In the Army, three divisions were shut down, and four divisions merged with other divisions. Similar types of arrangements were carried out in the Navy and in the Air force. The greatest savings consisted of personnel costs (around €91 million) and facilities costs (€13 million) (Defence Command 2016).

The structural changes, in turn, have affected the prospects and preconditions for individual employees to arrange their work and private lives. The changes were instructed to be implemented by using the good employer principles of state administration. The principles are the specific regulations for the organizations in the state administration to carry out organizational changes in a uniform way to secure the establishment of the personnel and to support the possession of changes and good-quality leadership. The regulations are based on the decision in principle of the government. In short, the cornerstones of the principles are providing open information, negotiating matters concerning the status of personnel, and, in the case of the FDF, supporting the transfer of personnel to new vacancies within the defense administration or to another employer (Ministry of Finance 2013).

The final report on the reform of the FDF written by the organization itself described the reform as a success. The reduction in the number of employees was accomplished 
mainly with various retirement arrangements. As a whole, the goals of the reform were reported to have been achieved and implemented within the planned schedule. However, the report stated that rising costs and investments in new technology and new equipment will require additional funding in the future (Defence Command 2016).

We approach the FDF organizational change by using the perspective of intersectionality with the aim of bringing more light to public sector changes. We focus on employee concerns and their connection to the experienced changes. In the following, we present some of the key points of intersectionality and critical realism as a framework for studying working life. In line with the ideas of critical realism, our purpose is to highlight certain mechanisms and patterns that explain results in this particular context (Hurrell 2014; Olsen \& Morgan 2005). Then, we describe the data (a large survey targeted to all organizational personnel) and the use of logistic regression as a quantitative method to explain employee concerns. In the findings, we bring together different stages of analysis and the main effects and the interaction effects of social categories and experienced changes. In the discussion and conclusion sections, we provide a summary of the results and an understanding of the importance of studying social divisions in organizational change processes.

\section{Theoretical framework and research questions}

Studies exploring the impact of belonging to multiple social categories and the power relations related to them have applied intersectional approaches with varying strategies and differing focuses. Intersectionality has been proposed as an important concept to enforce dialogue between gender research and working life research, as it is said to contribute to the critical and emancipatory edge of working life studies. The usefulness of the concept is argued to be based on how intersectionality may elaborate the understanding of work and labor and how central multiple inequalities are to the shaping, regulating, and experiencing working lives (Mulinari \& Selberg 2013, 82, 93-94). It has also been argued that addressing inequalities in work organizations requires understanding how differently organizations are experienced by, for example, women and men in various positions (Heiskanen et al. 2015; Otonkorpi-Lehtoranta et al. 2015).

In organizational studies, the original idea of intersectionality as giving an emancipatory voice to oppressed and marginalized groups is imported and applied to organizational identity construction, social systems, divisions, and structures to examine power relations in organizational settings. Some researchers have been worried about the consequences and implications of this kind of alienation from the empowering aims of US Black feminist theory, that is, at the root of the intersectionality (Davis \& Zarkov 2017,2). Without understating their concern, we think that intersectional approaches, as a method for analyzing processes and relations of power and inequality, give important insight not only into organizational settings but also in order to understand how inequalities are produced and sustained in the wider context of societies, as well as globally. This is because of the significant role of paid work and formal organizations in shaping power relations and societal gender and class inequalities, to name but a few (Jeanes et al. 2012).

One widely known and applied attempt to approach inequalities in organizations is Joan Acker's (2012a, 2012b) idea of inequality regimes. In line with Acker (2012a, 220), 
we think that studying 'how intersectionality actually works to produce inequalities' makes the concept a powerful tool. We suggest that by focusing on the specific organizational context and power relations with categories relevant in that peculiar context, it is possible to improve understanding of the various logics and forms of manifestations that discrimination can take. In our research, we are interested in what happens to social divisions when they are put into an organizational change context. Organizational change can change inequality processes, for example, by influencing hiring, wage setting, or promotion (Acker ibid).

To understand the complexity of the organizational change processes, it is necessary to specify conditions and contextual factors under which different social entities are related to each other and generate social structures and at the same time possibly produce inequalities. In line with critical realism, we consider that the description of occurrences and the processes to which these occurrences are connected have an important role in intersectional analysis of inequalities (Hurrell 2014, 241-244; O'Mahoney $\&$ Vincent 2014). A typical critical realist research design for research driven by critical realism is a case study, because it provides a situation in which the mechanisms and the processes leading to them can be studied in a specific context from multiple perspectives (Ackroyd \& Karlsson 2014, 25).

Previous research on the military and the social divisions among personnel revealed that concerns experienced by the personnel are related to interactions of gender, age, and personnel group. A strong civil/military hierarchy is interconnected to a gender hierarchy. These hierarchies function as a differentiating mechanism of privilege and disadvantage. Positions that are considered in or near the military core have primacy over the more marginal positions with more uncertain futures and less positive views on possibilities for self-development and career advancement. We suggested that gender hierarchy cannot be diminished without taking into account organizational processes concerning other examined social divisions: age and personnel group (OtonkorpiLehtoranta et al. 2015, 602-603). With the help of data collected at the end of the organizational reform, we aim to answer the question, how potent experienced changes are in explaining the concerns of the personnel, and how they possibly interact with social categories.

\section{Data and methodology}

Data are based on a survey addressed to all salaried personnel of the FDF in 2015. The response rate was 32\% (male respondents 30\% and female respondents 43\%, 3869 respondents in total). The proportion of women was $24 \%$ and men $76 \%$. Most of the female respondents were civilians $(86 \%)$, whereas most of the male respondents were soldiers $(78 \%)$. Among civilians, the proportion of women was $46 \%$ and men $54 \%$. Proportions of personnel in FDF in December 2015, proportions of respondents in the survey and response rates are presented in Table 1 . The data represent somewhat well the gender and personnel group, even if among civilians, female respondents are slightly over-represented. At the end of the questionnaire, respondents were also asked to write down suggestions for developing equality or whether they had something else to commentate. Thirty free text responses pertained directly to the organizational change. We return to these responses at the end of results section. 
Table I Proportions of personnel in Finnish Defense Forces in 2015, proportions of respondents in the survey, and response rates

\begin{tabular}{lrrr}
\hline & $\begin{array}{c}\text { Personnel in the Finnish } \\
\text { Defense Forces in December } \\
2015 \text { (number of employees } \\
\text { and percentages) }\end{array}$ & $\begin{array}{c}\text { Respondents (number } \\
\text { of employees who } \\
\text { responded and } \\
\text { percentages) }\end{array}$ & Response rate (\%) \\
\hline Civilian, female & $1905(15.8 \%)$ & $81 \mid(21.0 \%)$ & $42.6 \%$ \\
\hline Civilian, male & $2194(18.2 \%)$ & $647(16.7 \%)$ & $29.5 \%$ \\
\hline Civilians, total & $\mathbf{4 0 9 9 ( 3 4 . 0 \% )}$ & $\mathbf{1 4 5 8 ( 3 7 . 7 \% )}$ & $\mathbf{3 5 . 6 \%}$ \\
\hline Officer, female & $65(0.5 \%)$ & $38(1.0 \%)$ & $58.5 \%$ \\
\hline Officer, male & $284 \mid(23.6 \%)$ & $952(24.6 \%)$ & $33.5 \%$ \\
\hline Other soldier, female & $205(1.7 \%)$ & $92(2.4 \%)$ & $44.9 \%$ \\
\hline Other soldier, male & $4839(40.2 \%)$ & $1328(34.3 \%)$ & $27.4 \%$ \\
\hline Soldiers, total & $\mathbf{7 9 5 0 ( 6 6 . 0 \% )}$ & $\mathbf{2 4 1 0 ( 6 2 . 3 \% )}$ & $\mathbf{3 0 . 3 \%}$ \\
\hline Total & $\mathbf{1 0 0 . 0 \%}$ & $\mathbf{1 0 0 . 0} \%$ & $\mathbf{3 2 . 1 \%}$ \\
\hline
\end{tabular}

In this research, logistic regression was used in the analysis, because the dependent variables, concerns of respondents in the FDF, were dichotomous. In logistic regression, independent (explanatory) variables can be of a variety of levels of measurement, both continuous and categorical. It is also possible to use interaction terms between independent categorical variables to find out the structural relations between them (e.g., Olsen \& Morgan 2005; Tabachnick \& Fidell 2013). The overall fit of the statistical analysis was checked with the Hosmer and Lemeshow test, which measures the actual and predicted values of the dependent variable. The significance of the test should be more than 0.05 if the statistical model fit is adequate (Hair et al. 2010, 336-339). In this research, statistical analysis was carried out by using the SPSS statistics program.

The organizational changes can be detected in some descriptive findings from the data. More than $40 \%$ of respondents had had changes in their work tasks or moved to a new administrative unit. To examine these changes, the concerns of the FDF respondents were chosen as dependent variables (whether the respondent had concerns or not). They are concerns about one's job continuity, concerns about one's well-being at work, concerns about changes in organizing one's work, and concerns about changes in pay.

To study in which way the concerns were dependent on respondents' gender, age, and personnel group and on the changes the respondents had experienced, two changerelated variables were used. The first variable concerning the changes in FDF was changes in one's work tasks (whether the tasks were changed or not). The other variable was based on two separate questions concerning moving to a new administrative unit or moving to a new county (whether the respondent had experienced changes or not). The variable was named transfer due to organizational changes. In total, there were five independent variables in the analysis.

The analysis was carried out first so that only main effects were examined. After this, the interactions were added in the analysis, and main effects and interaction effects were examined. An interaction means the joint effect of two or more independent variables on the dependent variable. Actually, in multivariate analysis, the 
interaction effects should be examined before making any statements about the main effects (Hair et al., 405).

\section{Results}

Several statistically significant main effects were found in the first analysis. Women had more concerns about job continuity and concerns about well-being at one's work compared with men. Age and personnel group were statistically significant in explaining all the dependent variables. Older respondents (older than 50 years) had fewer concerns about job continuity than younger age groups. The youngest respondents (the 30 -yearsold or younger age group) had fewer concerns, but respondents in the 41- to 50-year-old age group had more concerns about one's well-being at work than respondents over the age of 50 years. The youngest respondents had fewer concerns about changes in organizing one's work and concerns about changes in pay than respondents over the age of 50 years. Civilians had more concerns about job continuity, concerns about changes in organizing one's work, and concerns about changes in pay compared with soldiers.

The employees of the FDF whose work tasks had changed had more concerns in all the dependent variables relative to the respondents whose work tasks had not changed. In addition, the respondents who had transferred due to organizational change had more concerns about one's job continuity, concerns about changes in one's work organization, and concerns about changes in pay than the respondents who had not moved.

To examine more closely the structural relations between explanatory variables, two-way interactions were included in the analysis. In the results, some of the statistically significant main effects disappeared, which refers to the interaction between independent variables (e.g., Grace-Martin 2017; Hair et al. 2010). In total, eight statistically significant interactions were found in the second analysis. Results of the second analysis are presented in Table 2. The main effects among the different categories can be seen in the odds ratio (OR) column in Table 2 . In the groups that had more concerns relative to the reference category, the OR is more than 1.0, and in the groups that had fewer concerns relative to the reference category, the OR is less than 1.0. The p values (Sig.) of the independent variables are also presented in Table 2 . At the bottom of the Table 2 are presented the results of the Hosmer and Lemeshow tests. None of the $p$ values in the test are statistically significant $(\mathrm{p}>0.05)$, which means that the overall model fit of the analysis is adequate.

The statistically significant main effects of age remained in explaining all the dependent variables, but the statistically significant main effect of gender disappeared when the dependent variables were concerns about one's job continuity and concerns about well-being at one's work. In addition, the statistically significant main effect of personnel group disappeared when the dependent variable was concerns about well-being at one's work but remained in explaining three other dependent variables.

Of the variables concerning the changes in FDF, the statistically significant main effect of changes in one's work tasks remained only in explaining concerns about changes in pay. In addition, the variable transfer due to organizational changes remained statistically significant only when the dependent variable was concerns about changes in pay.

Examining two-way interaction effects in logistic regression is more complicated than studying the main effects because there are two reference categories in the group 


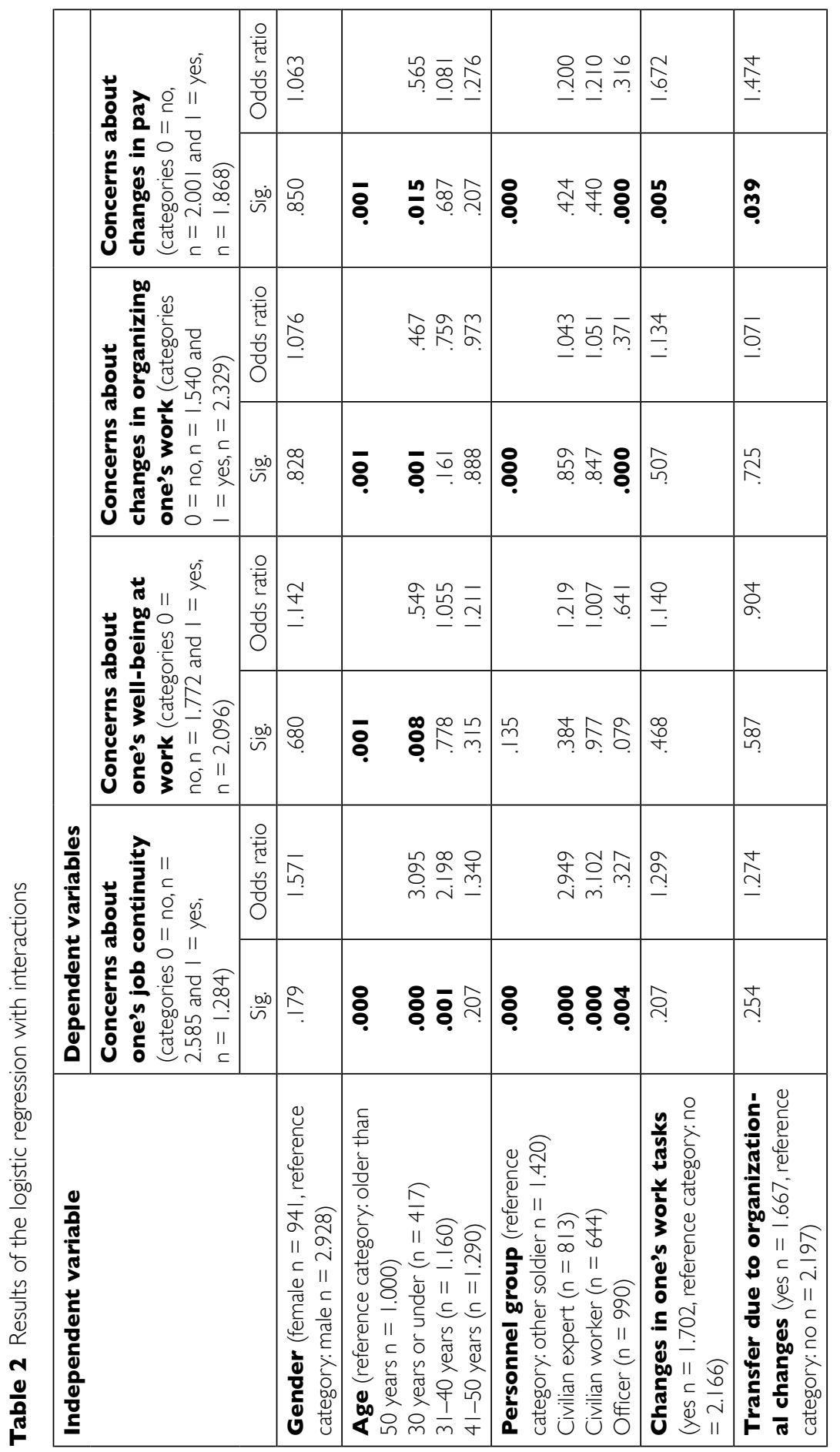




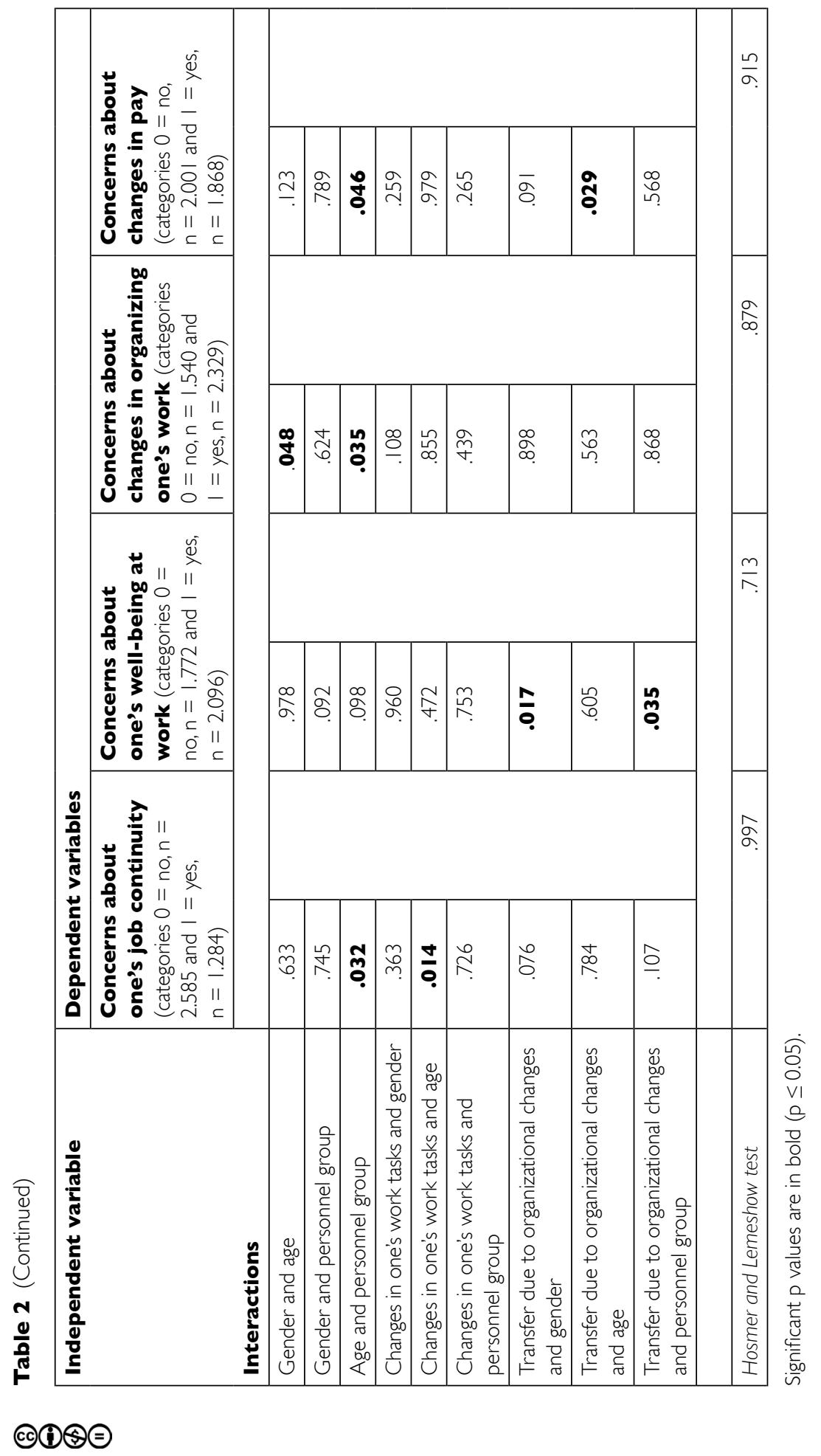


comparisons. The statistically significant interactions between categories depend on which groups are chosen as reference categories. However, a statistically significant interaction term for all respondents is not dependent on the reference categories. In Table 2, only the interaction effects between independent variables for all respondents are presented, and group comparisons in statistically significant interaction effects were conducted in a descriptive way by examining graphical plots of interactions (Figures 1 and 2). In Figures 1 and 2, the predicted probabilities for each category are presented on the vertical axes. The predicted probabilities are actually the same as the mean

Figure I: Statistically significant interactions explaining concerns about one's job continuity and concerns about well-being at one's work $(p \leq 0.05)$. (a) Concerns about one's job continuity: interaction between age and personnel group; (b) concerns about one's job continuity: interaction between changes in one's work tasks and age; (c) concerns about well-being at one's work: interaction between transfer due to organizational changes and gender; (d) concerns about well-being at one's work: interaction between transfer due to organizational changes and personnel group.

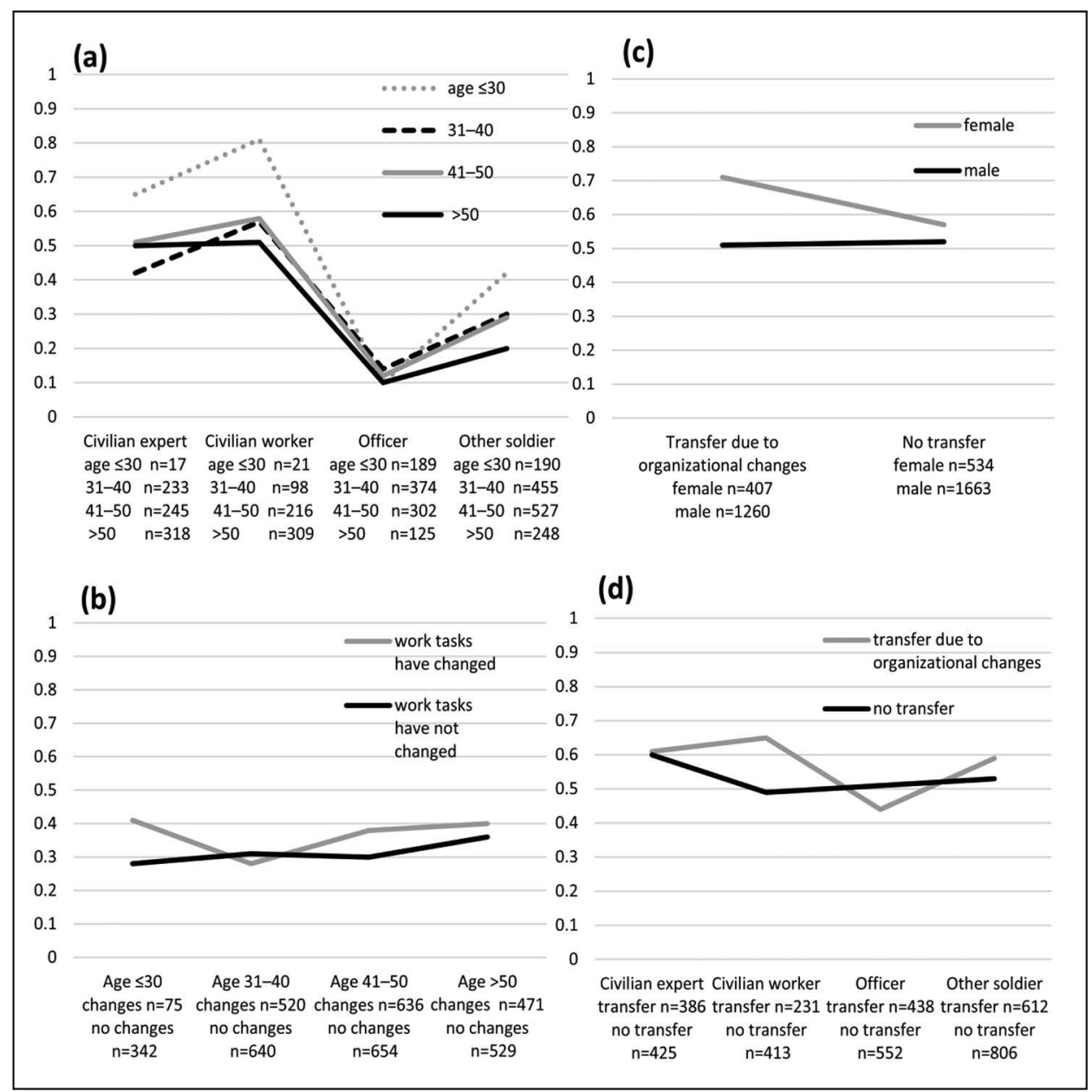


(in scale $0-1$ ) or the risk of having concerns for respondents in each category. A high probability indicates that respondents had more concerns in this category relative to the categories with lower probabilities (e.g., ESRC National Centre for Research Methods 2011).

There were two statistically significant interactions explaining concerns about $j o b$ continuity. The interaction between age and personnel group showed that civilian experts and workers had more concerns relative to officers and other soldiers. There was not much difference between age groups except the youngest civilian respondents, but the number of civilian respondents was low in these age categories [Figure 1, interaction (a)]. The other interaction between age and changes in one's work tasks showed that respondents whose work tasks had not changed did not have much variation in different age groups [Figure 1, interaction (b)]. Among the respondents whose work tasks had changed, the youngest and the two oldest age groups typically had more concerns relative to those whose work tasks had not changed. However, the 31- to 40-year-old age group did not have as many concerns even if their work tasks had changed. One possible explanation could be that the 31- to 40-year-old age group was the largest age group of officers who seemed to have fewer concerns than other personnel groups regardless of the changes the officers had experienced.

In explaining concerns about well-being at one's work, the interaction between gender and transfer due to organizational changes showed that female respondents who had faced changes had more concerns compared with those who had not. There was no difference in concerns for male respondents whether they had experienced changes or not [Figure 1, interaction (c)]. The other statistically significant interaction was between personnel group and transfer due to organizational changes. Respondents who had not experienced transfer effects had only small differences between personnel groups, except the civilian experts who had more concerns relative to other personnel groups [Figure 1, interaction (d)]. Among those who had experienced transfer effects, the most noteworthy result is that officers who had faced changes had fewer concerns relative to those who had not experienced changes. This is because $54 \%$ of the officers who had experienced transfer effects replied they had no concerns about well-being at their work. However, $51 \%$ of officers who had not experienced transfer effects replied they had concerns about well-being at their work.

In explaining concerns about changes in organizing one's work, there were two statistically significant interactions. First, the interaction between gender and age showed that female respondents in each age group had more concerns relative to male respondents. Among female respondents, the older than 50 years age group had more concerns than other age groups, and the difference compared to male respondents was higher than in other age groups. Among male and female respondents, the youngest age group had fewer concerns relative to others, and the difference between male and female respondents was small [Figure 2, interaction (e)]. The other statistically significant interaction was between age and personnel group. Officers in each age group had fewer concerns relative to other personnel groups even if the 31- to 40-year-old age group did not have much difference between the personnel groups [Figure 2, interaction (f)]. The youngest and oldest age groups of officers and the youngest civilian experts had only a few concerns, but among civilians, there were not many respondents in the youngest age group.

Finally, there were two statistically significant interactions explaining concerns about changes in pay. The interaction between age and personnel group showed in 
Figure 2: Statistically significant interactions explaining concerns about changes in organizing one's work and concerns about changes in pay $(p \leq 0.05)$. (e) Concerns about changes in organizing one's work: interaction between gender and age; $(f)$ concerns about changes in organizing one's work: interaction between age and personnel group; (g) concerns about changes in pay: interaction between age and personnel group; (h) concerns about changes in pay: interaction between transfer due to organizational changes and age.

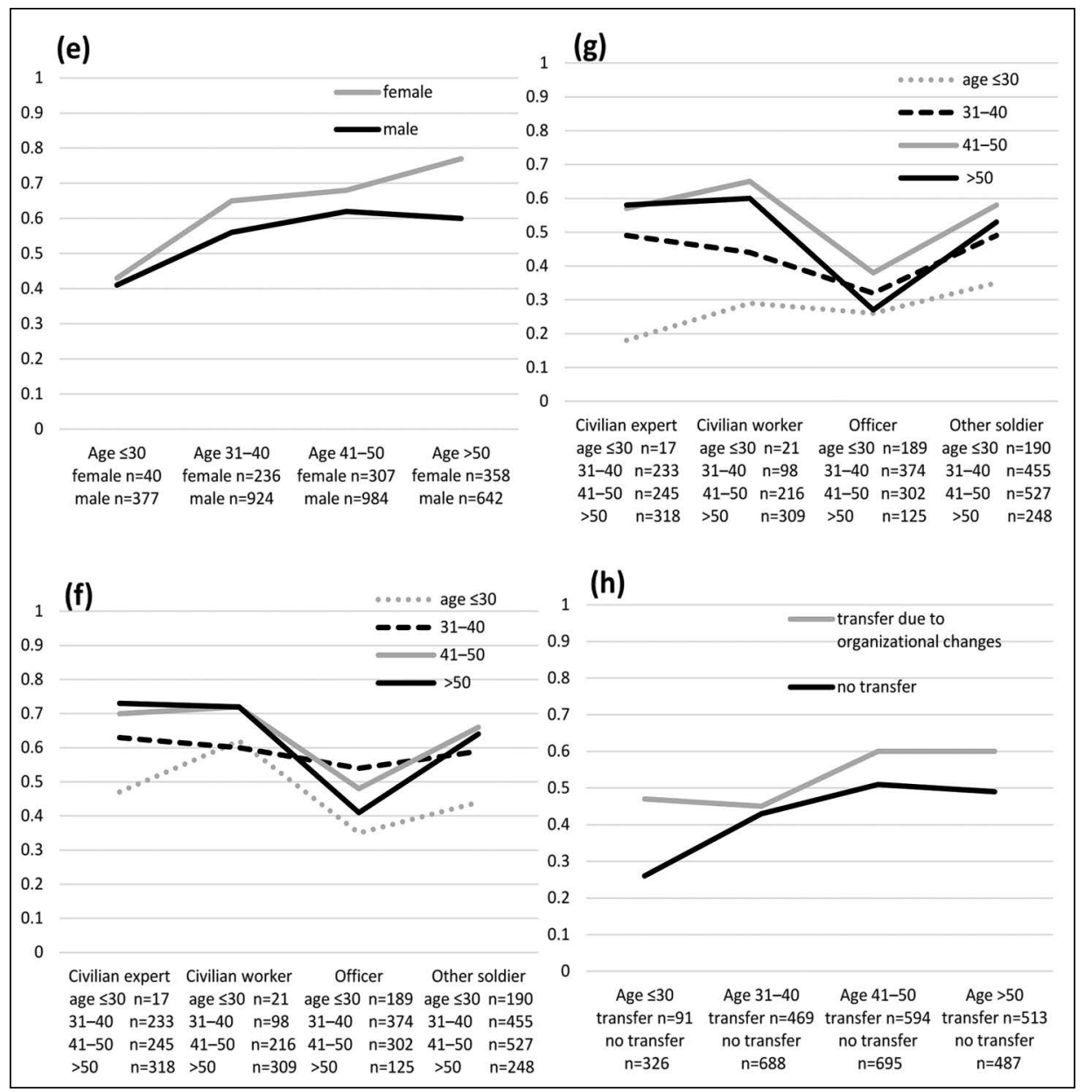

this case that officers in each age group had fewer concerns relative to other personnel groups and that the youngest respondents in each personnel group had fewer concerns compared with older respondents [Figure 2, interaction $(\mathrm{g})$ ]. Among the officers, the oldest age group had as few concerns as the youngest age group. Among the civilians and other soldiers, the two oldest age groups had more concerns relative to the two youngest age groups. The other statistically significant interaction was between age and transfer due to organizational changes. Respondents who had experienced changes had more concerns compared with those who had not [Figure 2, interaction (h)]. On 
average, younger age groups had fewer concerns relative to older age groups, including respondents who had experienced changes and those who had not. The difference was smallest for the 31- to 40-year-old age group. As mentioned above, this group was the largest age group of officers who did not seem to have as many concerns as the other personnel groups.

In answers to the open question at the end of questionnaire, employees spontaneously commented on the reform process. Layoffs and outsourcing were felt to have burdened the personnel. A weakening work climate was mentioned in forming new suborganizations in the FDF resulting from uneven sharing of tasks and struggles connected to different work cultures.

The most senior officers seldom made comments about the process; most of the responses came from civilians in expert positions, special officers, and warrant or noncommissioned officer positions. For civilians, their position in the organization had become more fragile as a result of the change. Women raised the issue of their gender as a definer of visibility and credibility.

I have always thought that in a military organization a civilian is kind of like visiting in a strange house with a particular style of living and in which those in the same family tree (soldiers) are eventually always loyal to each other and a civilian is left outside. Bear that in mind and accept that, and with humor, you'll manage. Over the last few years (in the heat of the Defence Forces reform), we have drifted apart. [...] It's just that I feel so often that I've become invisible, scentless, tasteless, nonexistent.

Woman, civilian, expert

Officers are at the core of the military. In addition to the statistical findings, this is shown in the open responses in which other personnel groups remarked that the layoffs did not apply to officers, and special arrangements could be made to ensure officers' positions in the organization. The concerns that officers raised (in addition to other military personnel) pertained to added hindrances to access to better positions and pay.

\section{Discussion}

The purpose of this study was to examine how the organizational changes carried out in the FDF during 2012-2015 have affected FDF employees. To examine this, the concerns of the FDF respondents were chosen as dependent variables. Independent variables were gender, age, personnel group, and two variables concerning the changes: changes in one's work tasks and experienced organizational changes. The latter variable was named transfer due to organizational changes. Logistic regression was used in analyzing the relations of the variables. First, only the main effects of the explanatory variables were examined. To examine more closely the relations of the independent variables, two-way interactions were added to the analysis.

There were several statistically significant main effects of independent variables explaining the four dependent variables. However, many of the statistically significant main effects disappeared when the interactions were included in the analysis. In total, eight statistically significant interactions explained the dependent variables. The variables concerning FDF organizational changes were interacted with other variables in 
explaining concerns about one's job continuity, concerns about well-being at one's work, and concerns about changes in pay.

Several statistically significant interactions between age and changes in one's work tasks explained concerns about one's job continuity. Respondents whose work tasks had changed had more concerns relative to those whose work tasks had not changed. However, in the 31-40 years age group, respondents whose work tasks had changed seemed to have even fewer concerns relative to those whose work tasks had not changed.

The interaction between gender and transfer due to organizational changes was statistically significant in explaining concerns about well-being at one's work. Female respondents who had experienced organizational changes had more concerns than female respondents who had not faced changes, but there was not much difference in the concerns of male respondents whether they had experienced changes or not. The other statistically significant interaction was between personnel group and transfer due to organizational changes. Civilian experts had more concerns compared with other personnel groups. Officers who had experienced organizational changes had fewer concerns relative to those who had not faced changes.

Finally, there was a statistically significant interaction between age and transfer due to organizational changes explaining concerns about changes in pay. Those who had faced organizational changes had more concerns relative to those who had not experienced changes, and on average, younger respondents had fewer concerns compared with older respondents. In addition, there were four other interactions between the variables concerning respondents' background. Three were between age and personnel group, and one was between gender and age.

On the basis of the studied interaction effects, the most noteworthy result was that the changes in the FDF did not affect male respondents' concerns very much whether they had experienced changes or not. This result is mostly due to male officers who did not seem to have as many concerns relative to the other personnel groups. For example, officers who had experienced organizational changes at their work had fewer concerns about well-being at their work compared with those who had not faced changes.

\section{Conclusion}

The analysis showed that the structural changes in the FDF influenced men and women differently. In accordance with our previous research, neither civil/military nor gender mechanisms have vanished or their effects diminished. On the contrary, downsizing of the organization and the rearrangements attached to this process have strengthened social divisions and inequalities in the FDF. The analysis indicated that the logic of the examined organizational changes-changes in one's work tasks and transfers due to organizational changes-complied with the organizational hierarchies.

The organization relied on good employer principles during the change process. However, in evaluating the success of the reform, the FDF approach was somewhat technical focusing on achieving aims within a specific time frame and reaching a certain degree of layoffs and savings. The research showed that personally experienced changes in work tasks and transferring from one working environment to another as part of the organizational change heightened the possibility of insecurity experienced in relation to 
several issues. It could be argued that those in marginalized positions, such as women in civilian occupations and men and women in worker positions, became even more marginalized. Officers were, in all accounts, more secure about their position, and the findings also accentuate the special characteristics of officer careers: the expected vertical development of career trajectories and salaries. Officers are expected to be mobile in order to advance in their careers, but in organizational changes, officers cannot always be certain that this mobility ensures them increasing benefits, such as pay (OtonkorpiLehtoranta 2017). In addition, officers who had experienced personal changes were typically more concerned about changes in pay than officers who had not. Otherwise, the experienced changes had little effect on officers.

The intersectionality lens makes it necessary to look for inequalities in places often left out of sight. Gender relations in the military have been usually studied by focusing on women and men in military roles such as officer positions (Carreiras etc.). Our research shows how civilians of the organization are positioned and valued and that it really makes a difference whether you are a civilian or not in addition to the gender category. This research highlights the necessity to address men at different intersections of social categories. In this case, the civil/military hierarchy and the personnel group (worker/ expert) were relevant. As a response to the concerns raised about the use of the concept of intersectionality, based on our research results, we conclude that in order to address various inequalities and privileges, it is important to make different positionalities visible, including men's. The intersectional approach helps to obliterate the notion that where there are no women, there are no inequality problems.

In relation to discussions on the effects of structural changes in the female-dominated public sector, the research findings illustrate the gendered nature of such changes: the assumed prestige of a male-dominated organization does not protect the women of the organization, but their position is left insecure and the effects hit women the hardest. In addition, in worker positions, men were also marginalized as a consequence of outsourcing. The FDF case shows the public sector reform as a downsizing project that manifests in the research finding that age and experienced changes were connected to insecurity in job continuity. Experienced changes did not evoke concerns in the young, and in other instances, they had less concerns than older employees.

As it is not possible to focus on all aspects of organizational change in a statistical study, some aspects of change processes might have been left out of consideration. In this study, we focused on changes in one's work tasks and transfers due to organizational changes. However, other characteristics of the examined organizational reform that have a bearing on producing inequalities may not have been included in this study. As a methodological limitation in this research, only two-way interactions were included in the logistic regression, because some of the categories examined were too small to include interactions with three or more independent variables in the analysis. Previous research and the possibilities for analysis with these data limit us in addressing various differences in our current research endeavors. Such issues as ethnicity and sexuality are outside our scope.

Indeed, military organizations in Europe are under constant change (cf. NorheimMartinsen 2016), and while there have been trends of demilitarization such as adjusting to NPM, the FDF aims at strengthening its legitimacy by holding on to conscription and by adopting the principle of total defence, which in short means the cooperation between different security officials in security related tasks. As a result, there are also 
processes of remilitarization of the society. These processes are not clearcut but can have contradictory effects. For example, in the public discussion, a new kind of service system as part of national defense has been suggested for all young citizens regardless of gender that would on the one hand compel everybody to choose some form of service, but on the other hand would possibly make it easier for men to choose another form of service than military. In one way or another, these discussions and policies bring military and security issues and the choices related to them closer to citizens.

Although, as Holmberg (2015) says, military as a policy area has come closer to other policy areas requiring more openness, according to our findings, this development does not seem to be reflected in the organizational change process of the FDF but has marginalized the civilian contribution to the organization much like Tallberg $(2009,2010)$ has previously concluded. Our research has shown this at the level of the personnel and in their concerns and expectations. Marginalization is something that is experienced and felt by the civilian personnel. The requirement for openness and transparency can be detected in the willingness to respond to the gender equality legislation by making research on gender issues possible and developing gender equality policies. In practice, this leaves several possibilities of how to understand gender equality, who it concerns, and how. The findings suggest that it is important to include gender mainstreaming in the implementation of organizational reforms. However, this should be followed by practical actions in order to prevent deepening of social divisions that produce inequalities.

\section{References}

Acker, J. (2012a). Gendered organizations and intersectionality: problems and possibilities, Equality, Diversity and Inclusion: An International Journal 31(3): 214-224.

Acker, J. (2012b). Theorizing gender, race, and class in organizations. In Jeanes, E. L., Knights, D. \& Martin, Patricia Y (eds) Handbook of Gender, Work \& Organization, The Atrium: A John Wiley and Sons Ltd, Publication: 65-80.

Ackroyd, S. \& Karlsson, J. C. (2014). Critical realism, research techniques, and research designs. In Edwards, P. K., O’Mahoney, J. \& Vincent, S. (eds.) Studying Organizations Using Critical Realism, Oxford: Oxford University Press.

Alvinius, A. \& Johansson, E. \& Larsson, G. (2016). Negative organizations: antecedents of negative leadership? In Watola, D. \& Woycheshin, D. (eds) Negative Leadership: International Perspectives, Kingston: Canadian Defence Academy Press: 57-74.

Bergström, O. \& Styhre, A. \& Thilander, P. (2014). Paradoxifying organizational change: Cynicism and resistance in the Swedish Armed Forces, Journal of Change Management 14(3): 384-404.

Carreiras, H. (2006). Gender and the Military. Women in the Armed Forces of Western Democracies, London: Routledge (Cass Military Studies).

Carreiras, H. \& Kümmel, G. (Eds.) (2008). Women in the Military and in Armed Conflict, wiesbaden: VS Verlag für Sozialwissenschaften \& Springer.

Davis; K. \& Zarkov, D. (2017). EJWS retrospective on intersectionality, European Journal of Women's Studies 24(4): 313-320.

Defence Command (2016). Puolustusvoimauudistuksen loppuraportti. [The Report of Defence Reformation.], Helsinki: Puolustusvoimat, Pääesikunta, Suunnitteluosasto.

ESRC National Centre for Research Methods (2011). Using Statistical Regression Methods in Education Research, Module 4: Binary Logistic Regression, Evaluating Interaction 
Effects. Re Store project. http://www.restore.ac.uk/srme/www/fac/soc/wie/research-new/ srme/modules/mod4/13/index.html. Accessed October 17, 2017.

Grace-Martin, K. (2017). Interpreting Interactions when Main Effects are Not Significant. The Analysis Factor. https://www.theanalysisfactor.com/interactions-main-effects-not-significant/. Accessed November 17, 2017.

Hair, J. F., Black, W. C., Babin, B. J. \& Andersson, R. E. (2010). Multivariate Data Analysis, 7th edition, New Jersey: Prentice Hall.

Heiskanen, T. Otonkorpi-Lehtoranta, K.; Leinonen, M. \& Ylöstalo, H. (2015). Gender Issues on Change Agenda: Practicing Intersectionality in Action Research, Gender, Work \& Organization. doi: http://onlinelibrary.wiley.com/doi/10.1111/gwao.12072/pdf, 1-17. Accessed June 29, 2018.

Herranen, O. (2015). Uusi julkisjohtaminen ja valtion tuottavuusohjelman kova ydin, Hallinnon tutkimus 34(1): 27-42.

Holmberg, A. (2015). A demilitarization process under challenge? The example of Sweden, Defence Studies 15(3): 235-253.

Hurrell, S. S. (2014). Critical realism and mixed methods research: Combining the extensive and intensive at multiple levels. In Edwards, P. K., O’Mahoney, J. \& Vincent, S. (eds) Studying Organizations Using Critical Realism, Oxford: Oxford University Press: 241-263.

Jeanes, E. L., Knights, D. \& Martin, Patricia Y. (2012). Editorial Introduction to Handbook of Gender, Work and Organization. In Jeanes, E. L., Knights, D. \& Martin, P. Y. (eds.) Handbook of Gender, Work \& Organization, The Atrium: A John Wiley and Sons Ltd, Publication: ix-xxix.

Kamp, A., Klemsdahl, L. \& Gonäs, L. (2013). Working in the public sector. Introduction to the thematic issue, Nordic Journal of Working Life Studies 3(2): 1-8.

Ministry of Finance (2013). Muutosturvasäännökset valtionhallinnossa 2013. [The Employment Protection Provisions Regarding Changes in the State Administration 2013.], Helsinki: Valtiovarainministeriö. http://vm.fi/documents/10623/307719/ Muutosturvas \%C3\%A4\%C3\%A4nn\%C3\%B6kset+valtionhallinnossa/858897067fd8-406b-a589-4b21e02ca2af. Accessed June 29, 2018.

Mulinari, P. \& Selberg, R. (2013). Intersectional directions in working life research: a proposal, Nordic Journal of Working Life Studies 3(3): 81-98.

Mustosmäki, A., Oinas, T. \& Anttila, T. (2016). Abating inequalities? Job quality at the intersection of class and gender in Finland 1977-2013, Acta Sociologica 60(3): 228-245.

Norheim-Martinsen, P. M. (2016). New sources of military change - armed forces as normal organizations, Defence Studies 16(3): 312-326.

Olsen, W. \& Morgan, J. (2005). A critical epistemology of analytical statistics: addressing the sceptical realist, Journal for the Theory of Social Behaviour 35(3): 255-284.

O'Mahoney, J. \& Vincent, S. (2014). Critical realism as an empirical project: a beginner's guide. In O’Mahoney, J. \& Vincent, S. (eds.) Studying Organizations Using Critical Realism, Oxford: Oxford University Press.

Otonkorpi-Lehtoranta, K. (2017). Sotilaat, työ ja perhe. [Soldiers, Work and Family], Tampere: University of Tampere.

Otonkorpi-Lehtoranta, K., Leinonen, M., Nikkanen R. \& Heiskanen, T. (2015). Intersections of gender, age and occupational group in the Finnish Defence Forces, Equality, Diversity and Inclusion: An international Journal 34(7): 593-607.

Sasson-Levy, O. (2017). Ethnicity and gender in militaries: an intersectional analysis. In Woodward, R. and Duncanson, C. (eds) The Palgrave International Handbook of Gender and the Military, London: Palgrave Macmillan.

Tabachnick, B. G. \& Fidell, L. S. (2013). Using Multivariate Statistics, 6th edition, Boston: Pearson Education. 
Tallberg, T. (2009). The Gendered Social Organisation of Defence: Two Ethnographic Case Studies in the Finnish Defence Forces. Economics and Society 193, Helsinki: Hanken School of Economics.

Tallberg, T. (2010). Kuviot uusiksi? Maanpuolustuksen organisointi ja turvallisuuden valtavirtaistaminen. [The organizing of national defence and mainstreaming of security]. In Jukarainen, P. and Terävä, S. (eds) Tasa-arvoinen turvallisuus? Sukupuolten yhdenvertaisuus suomalaisessa maanpuolustuksessa ja kriisinhallinnassa, Helsinki: Minerva Kustannus Oy: 27-35. 